\section{PEER-REVIEWED ARTICLE}

Food Protection Trends, Vol 41, No. 4, p. 380-388 Copyright 2021 , International Association for Food Protection 2900 100th Street, Suite 309, Des Moines, IA 50322-3855, USA
Reihane Moghassem Hamidi, Seyed Shahram Shekarforoush, * Saeid Hosseinzadeh and Sara Basiri

*Dept. of Food Hygiene and Public Health, School of Veterinary Medicine, Shiraz University, Shiraz, Iran, 71441-69155

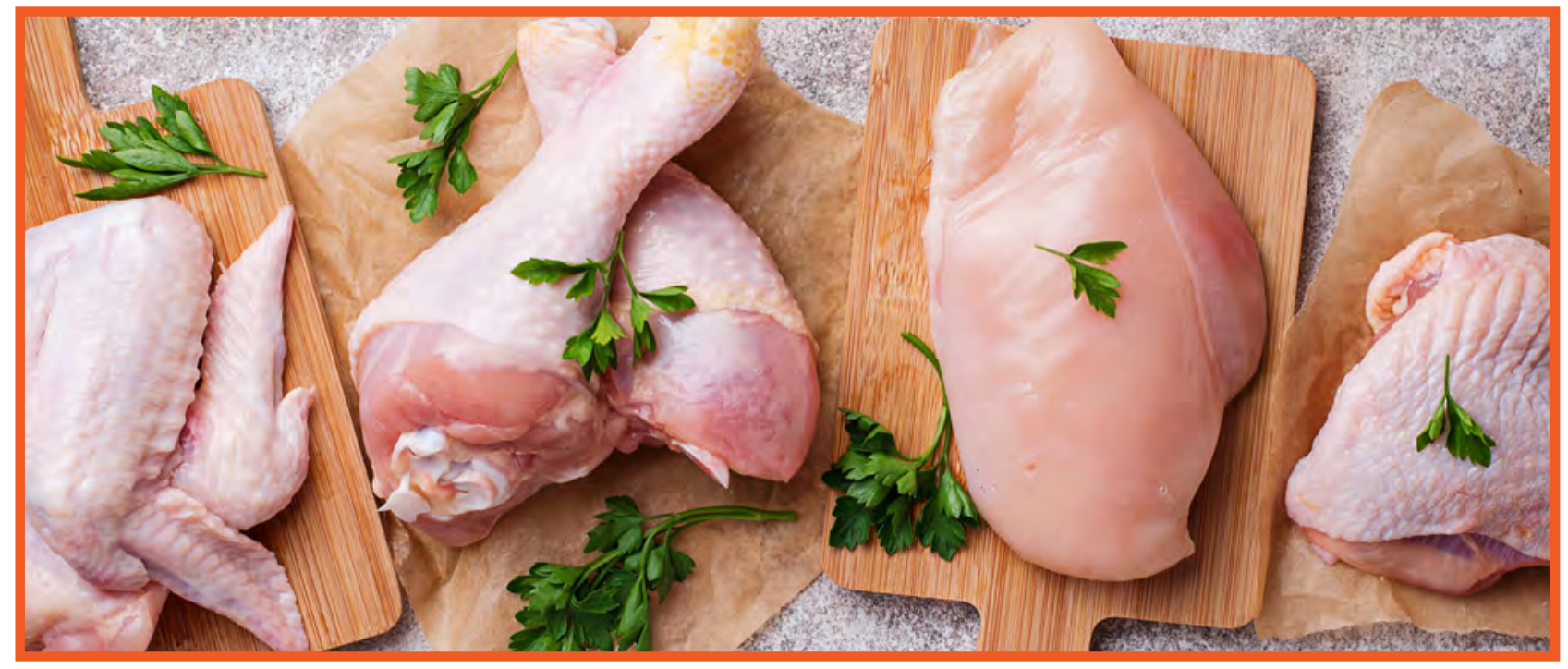

\title{
Near Neutral Electrolyzed Water and Peroxyacetic Acid and Their Effect on the Survival of Escherichia coli, Salmonella Typhimurium, and Listeria monocytogenes Inoculated on Poultry Meat
}

\section{ABSTRAGT}

This study was conducted to evaluate the antimicrobial efficacy of near-neutral electrolyzed water (NEW) and peroxyacetic acid (PAA) alone and in combination for reducing the foodborne pathogens Salmonella Typhimurium, Escherichia coli, and Listeria monocytogenes in pure culture and fresh chicken meat. The NEW treatments resulted in $100 \%$ inactivation of these organisms in pure culture at concentrations of 50, 100, and $200 \mu \mathrm{g} / \mathrm{mL}$ and 2 min of contact time at room temperature. The PAA treatments at concentrations of 100 and $200 \mu \mathrm{g} / \mathrm{mL}$ resulted in 100\% inactivation of the tested pathogens. The combination of NEW and PAA had a greater bactericidal effect than did each individual treatment. The inoculated chicken meat samples were dipped for $10 \mathrm{~min}$ in each treatment solutions (100 and $200 \mu \mathrm{g} / \mathrm{mL} \mathrm{NEW}, 200$ and $400 \mu \mathrm{g} / \mathrm{mL}$ PAA, $100 \mu \mathrm{g} / \mathrm{mL}$ $\mathrm{NEW}+200 \mu \mathrm{g} / \mathrm{mL}$ PAA] at room temperature. Samples dipped in water were used as a control. The greatest reduction was achieved with the combined treatment, which significantly $(P<0.05)$ reduced total cells and healthy cells of Salmonella Typhimurium, E. coli, and $L$. monocytogenes by 2.79 and $3.01,2.63$ and 2.75, and 1.47 and $1.99 \log$ CFU/g, respectively. The findings of this study indicate that a combined treatment with NEW and PAA has potential as a novel antimicrobial agent to improve the microbial safety of fresh chicken meat.

\section{INTRODUCTION}

The consumption of poultry meat has been increasing over the last decades due to its high nutritional value, low fat content, and low cost of production (10). Contamination of poultry meat with foodborne pathogens is an important human health issue, and food poisoning can result from mishandling of raw meat, careless processing, and storage $(22,37)$. Consumption of contaminated poultry products is a major cause of foodborne disease outbreaks (26). In some countries, decontamination procedures include chemical, physical, and biological treatments that are applied to reduce the prevalence of pathogens and microbial loads on poultry carcasses. Various chemical treatments have been developed in the meat and poultry industries to kill or inhibit microor- 
ganisms $(4,11)$. The disruption of physiological processes, cellular membranes, or other cellular constituents are the main antimicrobial activities of chemical compounds (34). However, most of these compounds have limitations, which include chemical residues, discoloration of meat, negative health effects on food handlers, corrosion of machinery, environmental pollution, and high costs $(40,42)$. Red meat and poultry decontamination technologies have been applied for years in the United States $(6,24)$. Electrolyzed water, a safe sanitizer, has been increasingly used in the food industry to reduce and control of microorganism on foods and food contact surfaces (23). Near-neutral electrolyzed water (NEW), with a $\mathrm{pH}$ of 6.0 to 6.8 , with an oxidation-reduction potential (ORP) of 800 to $900 \mathrm{mV}$, and containing $95 \%$ hypochlorous acid, $5 \%$ hypochlorite ion, and trace amounts of $\mathrm{Cl}_{2}$, is generated by passing an aqueous salt solution (ca. $1 \% \mathrm{NaCl}$ ) through a nonmembrane electrochemical cell $(21,33)$. Hypochlorous acid is the most active of the chlorine compounds and has high bactericidal activity (36). In several studies, the efficacy of NEW has been evaluated for reduction of bacterial population in fresh meat $(12,35,42,43)$, eggshells (44), seafoods (28), and vegetables (1). If NEW were to be combined with other chemical disinfectants such as organic acids, its antimicrobial efficacy might increase. Peroxyacetic acid (PAA) is produced from the reaction of acetic acid with hydrogen peroxide (31). Its disinfection efficiency is due to the strong oxidizing potential, which can result in disruption of the cell membrane and blockage of enzymatic and transport systems in microorganisms $(32,46)$. Application of PAA for meat decontamination has been studied $(3,30)$. The aim of the present study was to evaluate the efficacy of individual treatments with NEW and PAA and their combined effect on reduction of the foodborne pathogens Listeria monocytogenes, Salmonella Typhimurium, and Escherichia coli in vitro and in fresh chicken meat.

\section{MATERIALS AND METHODS \\ Bacterial cultures}

The bacterial strains used in this study were L. monocytogenes (PTCC 1297), Salmonella enterica subsp. enterica serovar Typhimurium (ATCC 14028), and E. coli (ATCC 35218) (School of Veterinary Medicine, Shiraz University, Shiraz, Iran). To confirm L. monocytogenes, cultures were streaked on PALCAM (polymyxin acriflavine lithium chloride ceftazidime aesculin mannitol) agar (Merck, Darmstadt, Germany) supplemented with nalidixic acid $(50 \mu \mathrm{g} / \mathrm{mL})$, amphotericin B $(10 \mu \mathrm{g} / \mathrm{mL})$, and acriflavin $(30 \mu \mathrm{g} / \mathrm{mL})$. For easy differentiation of E. coli and Salmonella Typhimurium from background bacteria of chicken breast meat, these pathogens were cultured to be resistant to nalidixic acid. Nonresistant cultures were inoculated into $100 \mathrm{~mL}$ of trypticase soy broth (TSB; Merck) and incubated at $37^{\circ} \mathrm{C}$ for $24 \mathrm{~h}, 100$ $\mathrm{mL}$ of TSB containing $200 \mu \mathrm{g} / \mathrm{mL}$ nalidixic acid (1451000, Sigma-Aldrich, St. Louis, MO) was added, and this culture was subsequently incubated at $37^{\circ} \mathrm{C}$ for a further $24 \mathrm{~h}$. A $0.1-\mathrm{mL}$ aliquot of this culture was spread on the surface of a trypticase soy agar (TSA; Merck) plate containing $100 \mu \mathrm{g} /$ $\mathrm{mL}$ nalidixic acid and incubated at $37^{\circ} \mathrm{C}$ for $24 \mathrm{~h}$. A single colony was selected and restreaked onto another TSA plate to confirm resistance to nalidixic acid (45). Each strain of pathogens was separately transferred into TSB with nalidixic acid $(50 \mu \mathrm{g} / \mathrm{mL})$ and incubated at $37^{\circ} \mathrm{C}$ for $24 \mathrm{~h}$, and $10 \mathrm{~mL}$ of each culture was then centrifuged at $4,000 \times \mathrm{g}$ for $10 \mathrm{~min}$. The supernatant was discarded, the cell pellet was washed twice with normal saline solution, and the final cell pellet was resuspended with the same solution. The density of the suspensions was compared to the $0.5 \mathrm{McF}$ arland turbidity standard and adjusted to $1.5 \times 10^{8} \mathrm{CFU} / \mathrm{mL}$.

\section{Preparation of disinfectant solutions}

NEW with a $\mathrm{pH}$ of 6.8 , an ORP of $830 \pm 5 \mathrm{mV}$, and available free chlorine (AFC) concentration of $800 \mu \mathrm{g} / \mathrm{mL}$ was obtained from Khosro Medisa Teb Co. (Envirolyte, Tehran, Iran). NEW was produced by electrolysis of a salt solution (ca. $1 \% \mathrm{NaCl}$ in tap water) with an electrolysis device. Solutions with various AFC concentrations were prepared with sterile distilled water. PAA was obtained from Behban Shimi Co. (Percidine 15\%, Golestan, Iran), and various concentrations were prepared with sterile distilled water $(\mathrm{v} / \mathrm{v})$.

\section{MIC determination for NEW and PAA}

The AFC concentration of NEW was measured with a chlorine test kit (Karizab Co., Tehran, Iran) immediately before use. The original NEW was then diluted with sterile distilled water to obtain AFC concentrations of 3.13, 6.25, $12.5,25,50,100$, and $200 \mu \mathrm{g} / \mathrm{mL}$. A $0.1-\mathrm{mL}$ aliquot of each bacterial suspension was combined with $9.9 \mathrm{~mL}$ of each concentration of NEW and vortexed for $5 \mathrm{~s}$ and then incubated at room temperature. The final level of each test pathogen per treatment was approximately $10^{6} \mathrm{CFU} /$ $\mathrm{mL}$. Sterile distilled water was used as a control for each experiment. To evaluate the effect of treatment time on the reduction of bacterial cells, treatment tubes were sampled at $0,1,2,3$, and $4 \mathrm{~min}$ after inoculation. The results indicated that no additional reduction was observed after $2 \mathrm{~min}$; therefore, 2 min of contact time at room temperature was chosen for the experiment. Following 2-min treatments, $0.1 \mathrm{~mL}$ of each sample was transferred to $9.9 \mathrm{~mL}$ of sterile neutralizing buffer $(0.5 \%$ sodium thiosulphate $+0.03 \mathrm{M}$ phosphate buffer solution), and the tubes were shaken. After neutralization, $0.1 \mathrm{~mL}$ of each treatment was plated on TSA with nalidixic acid and incubated at $37^{\circ} \mathrm{C}$ for 24 to $48 \mathrm{~h}$. The colonies were enumerated with the plate count method. When necessary, 10-fold serial dilutions were made from samples before plating. Using this method, the presence of low numbers of surviving cells may not be detected. In parallel, a $100-\mu \mathrm{L}$ aliquot of each treatment was added to 10 
$\mathrm{mL}$ of TSB with nalidixic acid and incubated at $37^{\circ} \mathrm{C}$ for 24 to $48 \mathrm{~h}$. Then, $100 \mu \mathrm{L}$ of enriched broth was spread onto TSA plates with nalidixic acid and incubated at $37^{\circ} \mathrm{C}$ for 24 to 48 h. The plates were then checked for bacterial colonies (19). The antibacterial effect of PAA at 3.13, 6.25, 12.5, 25, 50, 100 , and $200 \mu \mathrm{g} / \mathrm{mL}$ was also determined using the method described above.

To evaluate the antimicrobial interaction and any synergism between NEW and PAA, 3.13, 6.25, 12.5, 25 and $50 \mu \mathrm{g} / \mathrm{mL}$ concentrations of each disinfectant were prepared, and the same concentrations were mixed in equal proportions and tested according to the previous method.

\section{Sample preparation}

Whole fresh chicken breasts with skin were obtained from a local poultry processing plant. The breasts were transported in ice, stored at $4^{\circ} \mathrm{C}$, and used for treatments in $<2 \mathrm{~h}$. The average weight of each chicken breast sample was $400 \pm 30 \mathrm{~g}$.

\section{Inoculation of pathogens onto chicken meat samples}

Chicken breasts were randomly divided into three batches, each containing 54 samples. Samples in each batch were dipped for $10 \mathrm{~min}$ into separate bacterial suspensions of L. monocytogenes, nalidixic acid-resistant Salmonella Typhimurium, and nalidixic acid-resistant E. coli at $10^{7} \mathrm{CFU} /$ $\mathrm{mL}$ in sterile normal saline. The ratio of chicken meat sample to bacterial suspension volume was $1: 1(\mathrm{w} / \mathrm{v})$. For draining and bacterial attachment, the inoculated meat samples were placed on a grid plate inside a laminar flow hood at room temperature for $30 \mathrm{~min}$ (2). Inoculated untreated meat samples were tested to determine the levels of the pathogenic bacteria.

\section{Decontamination treatment}

Inoculated chicken meat samples in each batch were randomly divided into six groups, each containing nine samples. Five treatments of NEW at 100 and $200 \mu \mathrm{g} / \mathrm{mL}$, PAA at 200 and $400 \mu \mathrm{g} / \mathrm{mL}$, and NEW $100 \mu \mathrm{g} / \mathrm{mL}+$ PAA $200 \mu \mathrm{g} / \mathrm{mL}$ were prepared in a sterile chilled water container $\left(4^{\circ} \mathrm{C}\right)$. Sterilized chilled water was used to dip the control samples. Inoculated chicken meat samples with pathogens were dipped in treatment solutions for $10 \min (7,16,42)$. The ratio of chicken meat to treatment solution was $1: 1(\mathrm{w} / \mathrm{v})$. Following treatments, samples were drained for $10 \mathrm{~min}$ at room temperature, packed individually into sterile reclosable zippered polyethylene bags, and stored at $4 \pm 0.5^{\circ} \mathrm{C}$.

Noninoculated untreated chicken meat samples were tested for background contamination with L. monocytogenes, nalidixic acid-resistant Salmonella Typhimurium, and nalidixic acid-resistant E. coli.

\section{Microbiological analysis}

Treated inoculated chicken meat samples were tested immediately after treatment and on days 2 and 4 of storage. Samples were transferred to sterile stomacher bags and weighed, and sterilized $0.1 \%(\mathrm{w} / \mathrm{v})$ buffered peptone water (Merck) was added in at nine times the weight of each sample. To ensure that the samples were washed well, bags were hand massaged for $1 \mathrm{~min}$. The rinsate was then collected, ten-fold serial dilutions were made in sterile $0.1 \%$ buffered peptone water. PALCAM agar, xylose lysine deoxycholate (XLD) agar, and MacConkey agar, each supplemented with nalidixic acid, were used to count healthy cells of L. monocytogenes, Salmonella Typhimurium, and E. coli, respectively. A 100- $\mu \mathrm{L}$ aliquot of each sample or appropriate diluent was surface plated onto the appropriate medium and incubated at $37^{\circ} \mathrm{C}$ for 24 to $48 \mathrm{~h}$.

After disinfectant treatment, some microorganisms may be only injured rather than killed (48). For enumeration of injured bacterial cells, the overlay method was used (27). For each sample or appropriate diluent, $100 \mu \mathrm{L}$ was surface plated onto TSA and incubated at $37^{\circ} \mathrm{C}$ for 2 to $3 \mathrm{~h}$ to allow damaged bacterial cells to resuscitate, then agar plates overlaid with 7 to $12 \mathrm{~mL}$ of the appropriate selective medium. After the overlay solidified, the plates were incubated at $37^{\circ} \mathrm{C}$ for 24 to $48 \mathrm{~h}$. The difference in counts between selective (PALCAM agar, XLD agar, and MacConkey agar) and nonselective (overlay method) media was considered the count of injured cells. The percentage of injured bacterial cells was calculated by using the formula (20)

$\%$ injured cells $=\frac{\text { CFUnonselective }- \text { CFUselective }}{\text { CFUnonselective }} \times 100$

\section{Determination of residual chlorine}

For the residue experiment, chicken breast meat samples were dipped in $100 \mu \mathrm{g} / \mathrm{mL} \mathrm{NEW,} 200 \mu \mathrm{g} / \mathrm{mL} \mathrm{NEW}$, the combination treatment of $100 \mu \mathrm{g} / \mathrm{mL}$ NEW plus $200 \mu \mathrm{g} /$ $\mathrm{mL}$ PAA, and sterile water (control) and then placed in a grid plate inside a laminar flow hood at room temperature for $4 \mathrm{~h}$. After drying, the meat samples were rinsed in distilled water for $10 \mathrm{~min}$ at a $1: 2(\mathrm{w} / \mathrm{v})$ ratio of samples:distilled water. The rinse water was used for determination of residual chlorine with a chlorine test kit ( $N, N$-diethyl-p-phenylenediamine method; Karizab Co., Tehran, Iran).

\section{Statistical analysis}

The experiment was replicated three times. The data were analyzed with an analysis of variance in SPSS ver. 21 (SPSS Inc., IBM, Armonk, NY). Differences between treatments were assessed with Duncan's test and were considered significant at $P<0.05$.

\section{RESULTS AND DISCUSSION \\ MIC determination for NEW and PAA}

The bactericidal activity of NEW against pure cultures of E. coli, Salmonella Typhimurium, and L. monocytogenes during the 2 min of contact time is shown in Figure 1. At time 0, the initial populations of E. coli, Salmonella Typhimurium, 


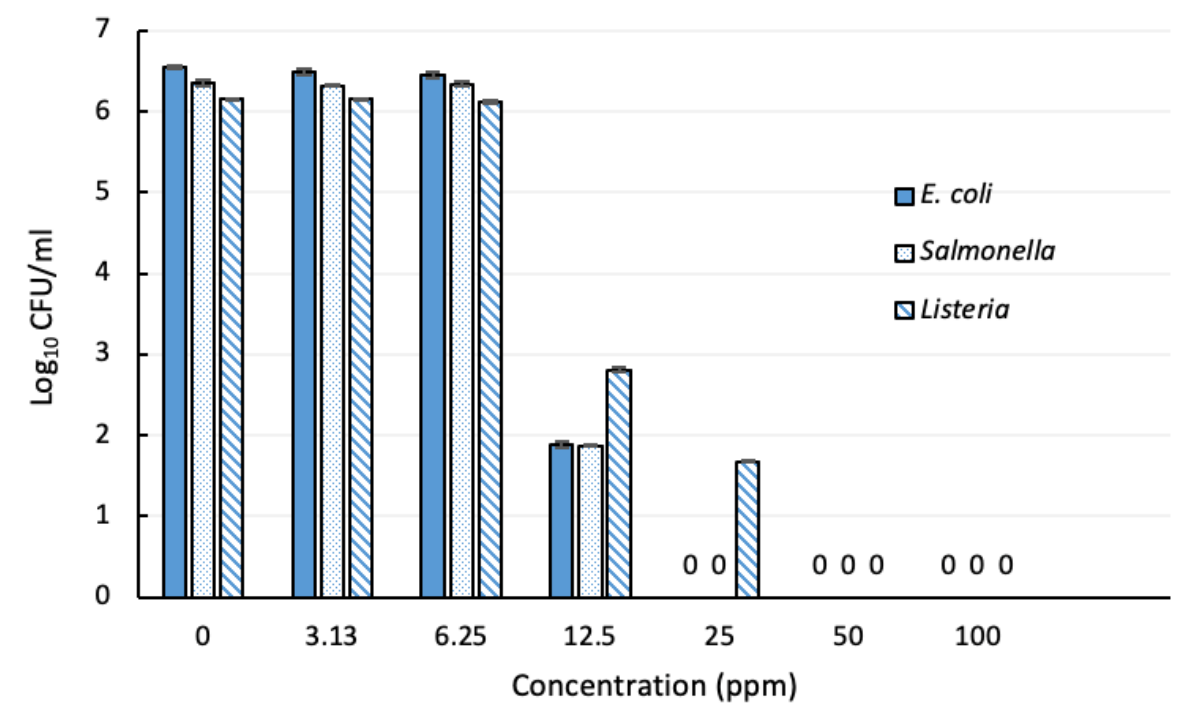

FIGURE 1. Effect of different concentrations of near-neutral electrolyzed water (NEW) on survival of E. coli, S. Typhimurium and L. monocytogenes after two minutes of exposure at $25^{\circ} \mathrm{C}$. Zero values indicate no detectable survivors by a direct plating procedure and enrichment experiment.

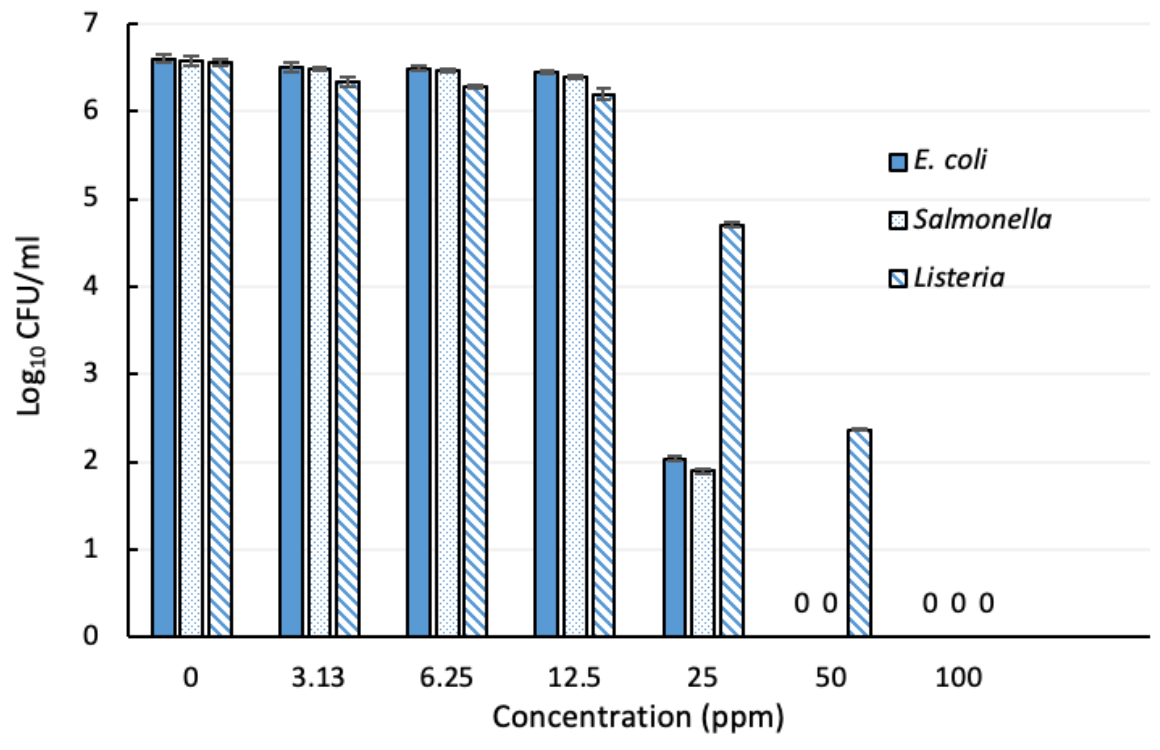

FIGURE 2. Effect of different concentrations of peroxyacetic acid (PAA) on survival of E. coli, S. Typhimurium and L. monocytogenes after two minutes of exposure at $25^{\circ} \mathrm{C}$. Zero values indicate no detectable survivors by a direct plating procedure and enrichment experiment. and L. monocytogenes were 6.45, 6.30, and 6.12 log CFU/ $\mathrm{mL}$, respectively. Listeria was more resistant than $E$. coli and Salmonella; the AFC concentration of $25 \mu \mathrm{g} / \mathrm{mL}$ completely eliminated E. coli and Salmonella Typhimurium but only reduced L. monocytogenes by $4.44 \log \mathrm{CFU} / \mathrm{mL}$. All microorganisms were completely eliminated when exposed to NEW at an AFC of $50 \mu \mathrm{g} / \mathrm{mL}$. Survivors were not detected by direct plating or after enrichment. Guentzel et al. (19) treated pure cultures of E. coli, Salmonella Typhimurium, Staphylococcus aureus, L. monocytogenes, and Enterococcus faecalis with NEW (pH 6.3 to 6.5; ORP 800 to 900 mV; 20, 50,100 , and $120 \mathrm{ppm}$ of total residual chlorine) and obtained $100 \%$ elimination of these organisms after $10 \mathrm{~min}$. However, in another study pure cultures of Salmonella Enteritidis were completely inactivated by NEW with an available chlorine concentration of $>4 \mu \mathrm{g} / \mathrm{mL}, \mathrm{pH}$ of 6.3 to 6.5 , and ORP of
251.0 to $297.2 \mathrm{mV}$ at 4,20 , and $45^{\circ} \mathrm{C}$ for $2 \mathrm{~min}$ (5). Several researchers have also reported complete elimination of $E$. coli O157:H7, Salmonella Enteritidis, and L. monocytogenes after treatment with acidic electrolyzed water (47).

PAA at $50 \mu \mathrm{g} / \mathrm{mL}$ effectively eliminated E. coli and Salmonella Typhimurium (survivors not detected by direct plating and culture enrichment), but the reduction of L. monocytogenes was only $3.75 \log \mathrm{CFU} / \mathrm{mL}$ (Fig. 2). At 25 and $12.5 \mu \mathrm{g} /$ $\mathrm{mL}, \mathrm{NEW}$ was more effective than PAA $(P<0.05)$.

The bactericidal effect of the combination of PAA and NEW against the three pathogens was higher than that of each disinfectant alone. The lowest concentration in the combined treatment required for complete inactivation of E. coli and Salmonella Typhimurium was $12.5 \mu \mathrm{g} / \mathrm{mL}$, and the lowest for complete inactivation of L. monocytogenes was $25 \mu \mathrm{g} / \mathrm{mL}$ (Fig. 3). In combination, lower concentrations of 


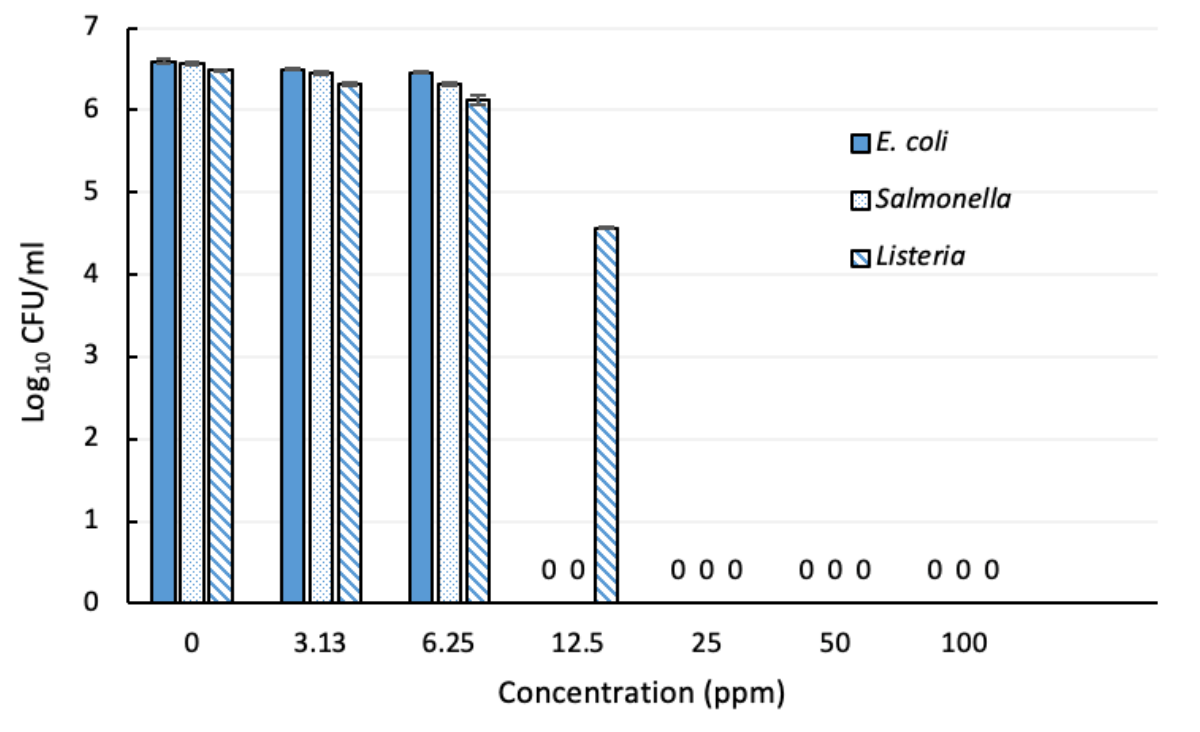

FIGURE 3. Effect of different concentrations of combination of NEW and PAA on survival of E. coli, $S$. Typhimurium and L. monocytogenes after two minutes of exposure at $25^{\circ} \mathrm{C}$. Zero values indicate no detectable survivors by a direct plating procedure and enrichment experiment.

NEW and PAA were required to eliminate these pathogens, and significantly greater bactericidal activity was achieved by the two disinfectants combined than was achieved by each disinfectant alone.

\section{Antimicrobial effect of treatments in fresh chicken meat}

L. monocytogenes and nalidixic acid-resistant Salmonella Typhimurium and E. coli were not detected in noninoculated untreated chicken meat samples. The initial mean $( \pm S D)$ populations of E. coli, Salmonella Typhimurium, and L. monocytogenes in chicken meat samples after inoculation were 6.92 $\pm 0.30,6.78 \pm 0.42$, and $6.12 \pm 0.32 \log \mathrm{CFU} / \mathrm{g}$, respectively.

NEW and PAA had destructive effects on these pathogens in chicken meat. However, reductions of the tested pathogens were lower in chicken meat than in the in vitro assay possibly because of the presence of organic materials and their protective effects on the pathogens.

Mean microbial reduction of healthy and total pathogen cells and the percentages of injured bacterial cells during 4 days of storage at $4^{\circ} \mathrm{C}$ are listed in Tables 1 and 2, respectively. A significant pathogen reduction was observed immediately after individual and combined treatments when compared with the water control, and further reduction of all tested pathogens was observed during 4 days of storage $(P<0.05)$. The reduction of pathogenic bacteria continued until day 4 of storage at $4^{\circ} \mathrm{C}$ probably because of the continued presence of strong antimicrobial compounds in NEW (hypochlorous acid and hypochlorite ion) and PAA (oxidizing compounds and undissociated acids) $(20,32,44)$.

L. monocytogenes was more resistant to all chemical solutions than were E. coli and Salmonella Typhimurium. NEW with AFC concentrations of 100 and $200 \mu \mathrm{g} / \mathrm{mL}$ reduced total cells of E. coli, Salmonella Typhimurium, and L. monocytogenes by 0.68 to $2.38 \log \mathrm{CFU} / \mathrm{g}$. The reduction achieved with $200 \mu \mathrm{g} /$ $\mathrm{mL} \mathrm{NEW}$ was significantly higher than that with $100 \mu \mathrm{g} / \mathrm{mL}$ for all three pathogens. Several researchers have assessed the effect of electrolyzed water on pork, chicken, and other meat samples for controlling E. coli, L. monocytogenes, Campylobacter coli, Campylobacter jejuni, and Salmonella Typhimurium and obtained reductions of 0.48 to $3.0 \log \mathrm{CFU} / \mathrm{g}(16,17,29,41)$. Guentzel et al. (19) reported that a 10-min dip of spinach leaves inoculated with E. coli, Salmonella Typhimurium, S. aureus, L. monocytogenes, and E. faecalis in NEW at 100 and $120 \mathrm{ppm}$ of total residual chlorine reduced all pathogens by 4.0 to $5.0 \log \mathrm{CFU} / \mathrm{mL}$. The efficacy of slightly acidic low concentration electrolyzed water (SlALcEW) and strong acidic electrolyzed water (StAEW) on inoculated fresh chicken breast meat against E. coli and L. monocytogenes was reported by Rahman et al. (42). SlALcEW and StAEW had similar antimicrobial effects, but SlALcEW was preferred because of its semineutral $\mathrm{pH}$ and low chlorine concentration. The reductions found in our study are lower than those previously reported. The differences observed are related to differences in the type of sample, dipping time, bacterial strain, level of bacterial attachment, and application method $(7,9,18,39)$.

Concentrations of 200 and $400 \mu \mathrm{g} / \mathrm{mL}$ PAA resulted in 0.99- to2.72-log reductions of total cells of the tested microorganisms. Similar to NEW, the reduction by $400 \mu \mathrm{g} /$ mL PAA was significantly higher than that from $200 \mu \mathrm{g} / \mathrm{mL}$ $(P<0.05)$. The antimicrobial effect of PAA is a result of its high ORP, which disrupts cell membrane permeability and alters protein synthesis. The second antimicrobial mechanism is acidification of the meat surface and penetration of the bacterial cell by undissociated acids (15).

Injured bacterial cells were detected in all treatment groups (Table 2). Detection of injured cells is important because these cells may be able to repair themselves and become functionally normal under favorable conditions (25). The production of injured cells and their reduction during 4 days of storage are indicative of the bacteriostatic and bactericidal effects of the 
TABLE 1. Reduction of inoculated pathogens in fresh chicken meat treated with different concentrations of peroxyacetic acid (PAA) and near-neutral electrolyzed water (NEW) during 4 days of storage at $4^{\circ} \mathrm{C}$

\begin{tabular}{|c|c|c|c|c|c|c|c|}
\hline \multirow[b]{3}{*}{$\begin{array}{l}\text { Storage } \\
\text { Time }\end{array}$} & \multirow[b]{3}{*}{ Treatments } & \multicolumn{6}{|c|}{ Bacterial reduction (mean $\pm \mathrm{SD}, \log \mathrm{CFU} / \mathrm{g}$ chicken meat) } \\
\hline & & \multicolumn{2}{|c|}{ E. coli } & \multicolumn{2}{|c|}{ Salmonella Typhimurium } & \multicolumn{2}{|c|}{ L. monocytogenes } \\
\hline & & Total cells & Healthy cells & Total cells & Healthy cells & Total cells & Healthy cells \\
\hline \multirow{6}{*}{$10 \mathrm{~min}$} & Control & $1.04 \pm 0.03^{\mathrm{Aa}}$ & $1.16 \pm 0.04^{\mathrm{Aa}}$ & $1.00 \pm 0.03^{\mathrm{Aa}}$ & $1.19 \pm 0.09^{\mathrm{Aa}}$ & $0.62 \pm 0.05^{\mathrm{Aa}}$ & $0.89 \pm 0.03^{\mathrm{Ba}}$ \\
\hline & PAA200 & $1.72 \pm 0.02^{\mathrm{Ac}}$ & $1.84 \pm 0.02^{\mathrm{Bc}}$ & $1.65 \pm 0.03^{\mathrm{Ac}}$ & $1.98 \pm 0.02^{\mathrm{Bb}}$ & $0.99 \pm 0.03^{\mathrm{Ac}}$ & $1.31 \pm 0.01^{\mathrm{Bc}}$ \\
\hline & PAA400 & $1.89 \pm 0.06^{\mathrm{Ae}}$ & $1.98 \pm 0.02^{\mathrm{Ad}}$ & $2.10 \pm 0.03^{\mathrm{Ae}}$ & $2.44 \pm 0.08^{\mathrm{Ad}}$ & $1.30 \pm 0.04^{\mathrm{Ae}}$ & $1.68 \pm 0.02^{\mathrm{Be}}$ \\
\hline & NEW100 & $1.55 \pm 0.02^{\mathrm{Ab}}$ & $1.77 \pm 0.02^{\mathrm{Bb}}$ & $1.57 \pm 0.04^{\mathrm{Ab}}$ & $1.92 \pm 0.05^{\mathrm{Bb}}$ & $0.68 \pm 0.05^{\mathrm{Ab}}$ & $1.10 \pm 0.05^{\mathrm{Bb}}$ \\
\hline & NEW200 & $1.82 \pm 0.01^{\mathrm{Ad}}$ & $2.00 \pm 0.02^{\mathrm{Bd}}$ & $1.74 \pm 0.05^{\mathrm{Ad}}$ & $2.30 \pm 0.06^{\mathrm{Bc}}$ & $1.14 \pm 0.02^{\mathrm{Ad}}$ & $1.45 \pm 0.04^{\mathrm{Bd}}$ \\
\hline & NEW100+ PAA200 & $1.96 \pm 0.06^{\mathrm{Af}}$ & $2.19 \pm 0.05^{\mathrm{Af}}$ & $2.12 \pm 0.02^{\mathrm{Ae}}$ & $2.58 \pm 0.05^{\mathrm{Be}}$ & $1.32 \pm 0.02^{\mathrm{Ae}}$ & $1.74 \pm 0.03^{\mathrm{Bf}}$ \\
\hline \multirow{6}{*}{2 days } & Control & $0.85 \pm 0.05^{\mathrm{Aa}}$ & $1.02 \pm 0.01^{\mathrm{Aa}}$ & $0.87 \pm 0.01^{\mathrm{Aa}}$ & $1.01 \pm 0.06^{\mathrm{Aa}}$ & $0.47 \pm 0.05^{\mathrm{Aa}}$ & $0.8 \pm 0.06^{\mathrm{Ba}}$ \\
\hline & PAA200 & $1.82 \pm 0.02^{\mathrm{Ac}}$ & $2.14 \pm 0.05^{\mathrm{Bc}}$ & $2.02 \pm 0.02^{\mathrm{Ac}}$ & $2.44 \pm 0.06^{\mathrm{Bc}}$ & $1.09 \pm 0.05^{\mathrm{Ac}}$ & $1.39 \pm 0.02^{\mathrm{Bc}}$ \\
\hline & PAA400 & $2.03 \pm 0.02^{\mathrm{Ad}}$ & $2.37 \pm 0.06^{\mathrm{Be}}$ & $2.37 \pm 0.06^{\mathrm{Ad}}$ & $2.58 \pm 0.05^{\mathrm{Ad}}$ & $1.34 \pm 0.06^{\mathrm{Ae}}$ & $1.75 \pm 0.02^{\mathrm{Ae}}$ \\
\hline & NEW100 & $1.72 \pm 0.05^{\mathrm{Ab}}$ & $2.02 \pm 0.01^{\mathrm{Bb}}$ & $1.66 \pm 0.02^{\mathrm{Ab}}$ & $2.28 \pm 0.13^{\mathrm{Bb}}$ & $0.81 \pm 0.02^{\mathrm{Ab}}$ & $1.21 \pm 0.06^{\mathrm{Bb}}$ \\
\hline & NEW200 & $2.17 \pm 0.05^{\mathrm{Ae}}$ & $2.29 \pm 0.02^{\mathrm{Ad}}$ & $2.05 \pm 0.05^{\mathrm{Ac}}$ & $2.55 \pm 0.03^{\mathrm{Bcd}}$ & $1.19 \pm 0.02^{\mathrm{Ad}}$ & $1.69 \pm 0.03^{\mathrm{Bd}}$ \\
\hline & NEW100+ PAA200 & $2.37 \pm 0.11^{\text {Af }}$ & $2.46 \pm 0.01^{\mathrm{Af}}$ & $2.41 \pm 0.02^{\mathrm{Ad}}$ & $2.73 \pm 0.05^{\mathrm{Be}}$ & $1.41 \pm 0.04^{\mathrm{Af}}$ & $1.87 \pm 0.03^{\mathrm{Bf}}$ \\
\hline \multirow{6}{*}{4 days } & Control & $0.71 \pm 0.06^{\mathrm{Aa}}$ & $0.97 \pm 0.03^{\mathrm{Ba}}$ & $0.68 \pm 0.01^{\mathrm{Aa}}$ & $0.79 \pm 0.02^{\mathrm{Aa}}$ & $0.41 \pm 0.01^{\mathrm{Aa}}$ & $0.71 \pm 0.03^{\mathrm{Ba}}$ \\
\hline & PAA200 & $2.07 \pm 0.03^{\mathrm{Ac}}$ & $2.48 \pm 0.01^{\mathrm{Bc}}$ & $2.16 \pm 0.05^{\mathrm{Ac}}$ & $2.65 \pm 0.03^{\mathrm{Bc}}$ & $1.15 \pm 0.04^{\mathrm{Ac}}$ & $1.43 \pm 0.01^{\mathrm{Bc}}$ \\
\hline & PAA400 & $2.27 \pm 0.05^{\mathrm{Ad}}$ & $2.68 \pm 0.04^{\mathrm{Be}}$ & $2.72 \pm 0.05^{\mathrm{Ae}}$ & $2.96 \pm 0.05^{\mathrm{Ae}}$ & $1.38 \pm 0.02^{\mathrm{Ae}}$ & $1.80 \pm 0.06^{\mathrm{Bd}}$ \\
\hline & NEW100 & $1.84 \pm 0.05^{\mathrm{Ab}}$ & $2.05 \pm 0.02^{\mathrm{Bb}}$ & $1.86 \pm 0.06^{\mathrm{Ab}}$ & $2.53 \pm 0.09^{\mathrm{Bb}}$ & $0.99 \pm 0.02^{\mathrm{Ab}}$ & $1.31 \pm 0.02^{\mathrm{Bb}}$ \\
\hline & NEW200 & $2.38 \pm 0.04^{\mathrm{Ae}}$ & $2.59 \pm 0.03^{\mathrm{Bd}}$ & $2.29 \pm 0.01^{\mathrm{Ad}}$ & $2.75 \pm 0.05^{\mathrm{Bd}}$ & $1.30 \pm 0.05^{\mathrm{Ad}}$ & $1.87 \pm 0.03^{\mathrm{Be}}$ \\
\hline & NEW100+ PAA200 & $2.63 \pm 0.05^{\mathrm{Af}}$ & $2.75 \pm 0.04^{\mathrm{Af}}$ & $2.79 \pm 0.01^{\mathrm{Af}}$ & $3.01 \pm 0.06^{\mathrm{Ae}}$ & $1.47 \pm 0.03^{\mathrm{Af}}$ & $1.99 \pm 0.02^{\mathrm{Bf}}$ \\
\hline
\end{tabular}

PAA200 and PAA400, PAA at 200 and $400 \mu \mathrm{g} / \mathrm{mL}$; NEW100 and NEW200, NEW at 100 and $200 \mu \mathrm{g} / \mathrm{mL}$ ); NEW100 + PAA200, $\mathrm{NEW}$ at $100 \mu \mathrm{g} / \mathrm{mL}+\mathrm{PAA}$ at $200 \mu \mathrm{g} / \mathrm{mL}$. Different lowercase letters indicate a significant difference between treatment groups within each storage day $(P<0.05)$. Different uppercase letters indicate a significant difference between the values of total cells and healthy cells within each treatment $(P<0.05)$.

treatments. The reduction of healthy cells was greater than that of the total cells for each pathogen, but in the some the differences were not significant (Table 2).

In our study, the greatest reduction was achieved with a combination of NEW and PAA compared with all individual treatments and the control $(P<0.05)$. With this combination treatment, maximum reductions during 4 days of storage for Salmonella Typhimurium, E. coli, and L. monocytogenes were $2.79 \pm 0.01,2.63 \pm 0.05$, and $1.47 \pm 0.03 \log \mathrm{CFU} / \mathrm{g}$, respectively, for total cells and 3.01 $\pm 0.06,2.75 \pm 0.04$, and $1.99 \pm$ 0.02 , respectively, for healthy cells. The second most effective compound was $200 \mu \mathrm{g} / \mathrm{mL} \mathrm{NEW} \mathrm{for} \mathrm{E.} \mathrm{coli} \mathrm{and} 400 \mu \mathrm{g} / \mathrm{mL}$ PAA for Salmonella Typhimurium and L. monocytogenes. The enhanced antimicrobial effect of the combined NEW plus PAA treatment revealed the synergistic properties of these disinfectants. When PAA was added to NEW, the $\mathrm{pH}$ and AFC of the combined solution were reduced, but the ORP increased. These factors are responsible for the higher bactericidal activity of the combined treatment, even though the AFC was reduced (35). McPherson (38) and Carlson (8) stated that the ORP value of the solution was more important than the concentration of free or total chlorine. Park et al. (41) reported that the high ORP of electrolyzed water could cause modification of metabolic fluxes and ATP production, probably due to the change in the electron flow in the cells. Electron microscopy and fluorescent measurements indicated that the ORP affects E. coli O157:H7 by damaging the outer and inner membranes (33). 
TABLE 2. Percentage of injured cells of three pathogenic bacteria in fresh chicken meat after treatment with different concentrations of peroxyacetic acid (PAA) and near-neutral electrolyzed water (NEW) during 4 days of storage at $4^{\circ} \mathrm{C}$

\begin{tabular}{|c|c|c|c|c|}
\hline \multirow[b]{2}{*}{ Storage Time } & \multirow[b]{2}{*}{ Treatment } & \multicolumn{3}{|c|}{ Injured cells (\%) } \\
\hline & & E. coli & Salmonella Typhimurium & L.monocytogenes \\
\hline \multirow{6}{*}{$10 \mathrm{~min}$} & Control & $23.5^{\mathrm{a}}$ & $34.66^{\mathrm{a}}$ & $47.0^{\mathrm{a}}$ \\
\hline & PAA200 & $23.0^{\mathrm{a}}$ & $52.85^{\mathrm{b}}$ & $52.0^{\mathrm{ab}}$ \\
\hline & PAA400 & $18.8^{\mathrm{a}}$ & $52.71^{\mathrm{b}}$ & $57.6^{\mathrm{bc}}$ \\
\hline & NEW100 & $38.3^{\mathrm{b}}$ & $54.83^{\mathrm{b}}$ & $59.4^{\mathrm{d}}$ \\
\hline & NEW200 & $35.9^{\mathrm{b}}$ & $72.54^{\mathrm{c}}$ & $51.0^{\mathrm{a}}$ \\
\hline & NEW100 + PAA200 & $41.0^{\mathrm{b}}$ & $64.72^{\mathrm{bc}}$ & $61.7^{\mathrm{d}}$ \\
\hline \multirow{6}{*}{2 days } & Control & $31.8^{\mathrm{ab}}$ & $26.58^{\mathrm{a}}$ & $54.8^{\mathrm{ab}}$ \\
\hline & PAA200 & $52.4^{c}$ & $61.46^{\mathrm{bc}}$ & $49.8^{\mathrm{a}}$ \\
\hline & PAA400 & $53.9^{\mathrm{c}}$ & $37.75^{\mathrm{a}}$ & $62.2^{\mathrm{cd}}$ \\
\hline & NEW100 & $50.3^{\mathrm{bc}}$ & $75^{\mathrm{d}}$ & $60.1^{\mathrm{bc}}$ \\
\hline & NEW200 & $22.2^{\mathrm{a}}$ & $68^{\mathrm{cd}}$ & $68.8^{\mathrm{d}}$ \\
\hline & NEW100 + PAA200 & $22.3^{\mathrm{a}}$ & $51.73^{\mathrm{b}}$ & $65.2^{\mathrm{cd}}$ \\
\hline \multirow{6}{*}{4 days } & Control & $44.0^{\mathrm{bc}}$ & $22.2^{\mathrm{a}}$ & $33.7^{\mathrm{a}}$ \\
\hline & PAA200 & $60.7^{c}$ & $67.83^{\mathrm{c}}$ & $47.6^{\mathrm{b}}$ \\
\hline & PAA400 & $61.0^{\mathrm{c}}$ & $42.14^{\mathrm{b}}$ & $62.2^{\mathrm{c}}$ \\
\hline & NEW100 & $37.8^{\mathrm{ab}}$ & $80^{\mathrm{d}}$ & $52.5^{\mathrm{b}}$ \\
\hline & NEW200 & $38.8^{\mathrm{ab}}$ & $65.24^{\mathrm{c}}$ & $71.6^{\mathrm{d}}$ \\
\hline & NEW100 + PAA200 & $25.3^{\mathrm{a}}$ & $38.55^{\mathrm{b}}$ & $64.5^{\mathrm{cd}}$ \\
\hline
\end{tabular}

PAA200 and PAA400, PAA at 200 and $400 \mu \mathrm{g} / \mathrm{mL}$; NEW100 and NEW200, NEW at 100 and $200 \mu \mathrm{g} / \mathrm{mL}$ ); NEW100 + PAA200, $\mathrm{NEW}$ at $100 \mu \mathrm{g} / \mathrm{mL}+\mathrm{PAA}$ at $200 \mu \mathrm{g} / \mathrm{mL}$. Different letters indicate a significant difference between treatment groups within each storage day $(P<0.05)$.

\section{Chlorine and PAA residues}

Measurement of the residual chlorine on the meat samples revealed that the $100 \mu \mathrm{g} / \mathrm{mL} \mathrm{NEW}$, combined treatment, and control groups had no residues, although NEW at $200 \mu \mathrm{g} / \mathrm{mL}$ left $0.3 \mu \mathrm{g} / \mathrm{mL}$ residual chlorine on meat samples, which was acceptable and considered safe for consumption. A maximum residue limit of $0.7 \mathrm{mg} / \mathrm{L}$ was stipulated by the European Food Safety Authority (EFSA) (14) in the European Union for all foodstuffs and drinking water.

In this study, the residual PAA was not evaluated because previous research has indicated that PAA is highly reactive and, when used in the presence of organic compounds, dissociates very rapidly and breaks down to acetic acid and water. According to the EFSA (13), the residues of peroxyacids and hydrogen peroxide in chicken carcasses after dipping for $60 \mathrm{~min}$ in PAA solution $(200 \mathrm{mg} / \mathrm{L})$ were below the detection limit of $1 \mathrm{mg} / \mathrm{L}$; thus, it is not necessary to subsequently remove the PAA solution from the poultry carcasses or poultry meat.

\section{CONCLUSION}

The results of the present study revealed that treating fresh chicken meat with NEW and PAA effectively reduced populations of Salmonella Typhimurium, E. coli, and L. monocytogenes immediately after the treatment and during storage at $4^{\circ} \mathrm{C}$. Combined treatment with NEW and PAA significantly reduced populations of inoculated foodborne pathogens compared with NEW and PAA treatments alone. This combined treatment is a beneficial decontamination method and can improve the microbiological safety of chicken meat. The effectiveness of combined NEW plus PAA on the microbiological shelf life and some meat quality variables such as $\mathrm{pH}$, lipid oxidation, and color is being evaluated. Further study is needed to evaluate the efficacy 
of NEW plus PAA or other organic acids with different treatment methods and dipping times in commercial slaughter plants and in other meat products.

\section{ACKNOWLEDGMENTS}

This research was financially supported by Shiraz University and is gratefully acknowledged. The authors thank Khosro Medisa Teb Co. for donating the electrolyzed water, and Mrs. Zahra MacCohen for editing the manuscript.

\section{REFERENCES}

1. Abadias, M., J. Usall, M. Oliveira, I. Alegre, and I. Vinas. 2008. Efficacy of neutral electrolyzed water (NEW) for reducing microbial contamination on minimallyprocessed vegetables. Int. J. Food Microbiol. 123:151-158.

2. Alonso-Hernando, A., C. Alonso-Calleja, and R. Capita. 2015. Effect of various decontamination treatments against grampositive bacteria on chicken stored under differing conditions of temperature abuse. Food Control 47:71-76.

3. Bauermeister, L. J., J. W. J. Bowers, J. C. Townsend, and S. R. McKee. 2008. The microbial and quality properties of poultry carcasses treated with peracetic acid as an antimicrobial treatment. Poult. Sci. $87: 2390-2398$.

4. Bolder, N. M. 2007. Microbial challenges of poultry meat production. World Poult. Sci.J. 63:401-411.

5. Cao, W., Z. W. Zhu, Z. X. Shi, C. Y. Wang, and B. M. Li. 2009. Efficiency of slightly acidic electrolyzed water for inactivation of Salmonella Enteritidis and its contaminated shell eggs. Int. J. Food Microbiol. 130:88-93.

6. Capita, R., C. Alonso-Calleja, M. C. García-Fernández, and B. Moreno. 2002. Review: trisodium phosphate treatment for decontamination of poultry. Food Sci. Technol. Int. 8:11-24.

7. Capita, R., C. Alonso-Calleja, M. Prieto, M. C. García-Fernández, and B. Moreno. 2003. Effectiveness of trisodium phosphate against Listeria monocytogenes on excised and non-excised chicken skin. J. Food Prot. 66:61-64.

8. Carlson, S. 1991. Fundamentals of water disinfection. J. Water Supply Res. Technol. Aquatics 40:346-356.

9. Castillo, A., L. M. Lucia, G. K. Kemp, and G. R. Acuff. 1999. Reduction of Escherichia coli O157:H7 and Salmonella Typhimurium on beef carcass surfaces using acidified sodium chloride. J. Food Prot. 62:580-584.

10. Chouliara, E., A. Karatapanis, I. N. Savvaidis, and M. G. Kontominas 2007. Combined effect of oregano essential oil and modified atmosphere packaging on shelf-life extension of fresh chicken breast meat, stored at $4^{\circ} \mathrm{C}$. Food Microbiol. 24:607-617.

11. Dincer, A. H., and T. Baysal. 2004. Decontamination techniques of pathogen bacteria in meat and poultry. Crit. Rev. Microbiol. 30:197-204.
12. Ding, T., S. M. E. Rahman, U. Purev, and D. H. Oh. 2010. Modelling of Escherichia coli $\mathrm{O} 157: \mathrm{H} 7$ growth at various storage temperatures on beef treated with electrolyzed oxidizing water. J. Food Eng. 97:497-503.

13. EFSA Panel on Biological Hazards (BIOHAZ). 2014. Scientific opinion on the evaluation of the safety and efficacy of peroxyacetic acid solutions for reduction of pathogens on poultry carcasses and meat. EFSA J. 12:3599. https://doi.org/10.2903/j. efsa.2014.3599.

14. EFSA Panel on Contaminants in the Food Chain (CONTAM). 2015. Risks for public health related to the presence of chlorate in food. EFSA J. 13:4135-4238. https://doi. org/10.2903/j.efsa.2015.4135.

15. European Commission. 2003. Opinion of the Scientific Committee on Veterinary Measures Relating to Public Health on the evaluation of antimicrobial treatments for poultry carcasses. Adopted on 14-15 April 2003. European Commission, Brussels.

16. Fabrizio, K. A., and C. N. Cutter. 2005. Application of electrolyzed oxidizing water to reduce Listeria monocytogenes on ready-to-eat meats. Meat Sci. 71:327-333.

17. Fabrizio, K. A., R. R. Sharma, A. Demirci, and C. N. Cutter. 2002. Comparison of electrolyzed oxidizing water with various antimicrobial interventions to reduce Salmonella on poultry. Poult. Sci. 66:13791384

18. Gill, C. O., and M. Badoni. 2004. Effects of peroxyacetic acid, acidified sodium chlorite or lactic acid solutions on the microflora of chilled beef carcasses. Int. J. Food Microbiol. 91:43-50.

19. Guentzel, J. L., K. L. Lam, M. A. Callan, S. A. Emmons, and V. L. Dunham. 2008. Reduction of bacteria on spinach, lettuce, and surfaces in food service areas using neutral electrolyzed oxidizing water. Food Microbiol. 25:36-41.

20. Hansen, T. B., and S. Knochel. 2001. Factors influencing resuscitation and growth of heat injured Listeria monocytogenes 13-249 in sous vide cooked beef. Int. J. Food Microbiol. 63:135-147.

21. Honda, Y. 2003. Improvement of the electrolysis equipment and application of slightly acidic electrolyzed water for dairy farming. J. Jpn. Soc. Agric. Mach. 65:27-29.
22. Hong, Y. H., G. J. Ku, M. K. Kim, and K. B. Song. 2007. Inactivation of Listeria monocytogenes and Campylobacter jejuni in chicken by aqueous chlorine dioxide treatment. J. Food Sci. Nutr. 12:279-283.

23. Hricova, D., R. Stephan, and C. Zweifel. 2008. Electrolyzed water and its application in the food industry. J. Food Prot. 71:19341947.

24. Hugas, M., and E. Tsagarida. 2008. Pros and cons of carcass decontamination: the role of the European Food Safety Authority. Meat Sci. 78:43-52.

25. Jay, J. M., M. J. Loessner, and D. A. Golden. 2005. Culture, microscopic, and sampling methods, chap. 10, p. 229-233. In Modern food microbiology, 7 th ed. Springer, New York.

26. Jiménez, S. M., P. Destefanis, M. S. Salsi, M. C. Tiburzi, and M. E. Pirovani. 2005. Predictive model for reduction of Escherichia coli during acetic acid decontamination of chicken skin. J. Appl. Microbiol. 99:829-835.

27. Kang, D. H., and D. Y. Fung. 2000. Application of thin layer method for recovery of injured Salmonella Typhimurium. Int. J. Food Microbiol. 54:127-132.

28. Khazandi, M., P. Deo, S. Ferro, H. Venter, H. Pi, S. Crabb, T. Amorico, A. D. Ogunniyi, and D. J. Trott. 2017. Efficacy evaluation of a new water sanitizer for increasing the shelf life of southern Australian King George Whiting and Tasmanian Atlantic Salmon fillets. Food Microbiol. 68:51-60.

29. Kim, C., Y. C. Hung, and S. M. Russell 2005. Efficacy of electrolyzed water in the prevention and removal of fecal material attachment and its microbicidal effectiveness during simulated industrial poultry processing. Poult. Sci. 84:1778-1784.

30. King, D. A., L. M. Lucia, A. Castillo, G. R. Acuff, K. B. Harris, and J. W. Savell. 2005. Evaluation of peroxyacetic acid as a postchilling intervention for control of Escherichia coli O157:H7 and Salmonella Typhimurium on beef carcass surfaces. Meat Sci. 69:401-407.

31. Kitis, M. 2004. Disinfection of wastewater with peracetic acid: a review. Environ. Int. J. 30:47-55.

32. Koivunen, J., and H. Heinonen-Tanski. 2005. Inactivation of enteric microorganisms with chemical disinfectants, UV irradiation and combined chemical/UV treatments. Water Res. 39:1519-1526. 
33. Liao, L. B., W. M. Chen, and X. M. Xiao. 2007. The generation and inactivation mechanism of oxidation-reduction potential of electrolyzed oxidizing water. J. Food Eng. 78:1326-1332.

34. Loretz, M., R. Stephan, and C. Zweifel. 2010. Antibacterial activity of decontamination treatments for cattle hides and beef carcasses. Food Control 22:347-359.

35. Mansur, A. R., C. N. Tango, G. H. Kim, and D. H. Oh. 2015. Combined effects of slightly acidic electrolyzed water and fumaric acid on the reduction of foodborne pathogens and shelf-life extension of fresh pork. Food Control 47:277-284.

36. Marriott, N. G., and R. B. Gravani. 2006. Principles of food sanitation, 5th ed. Springer, New York.

37. Mbata, T. I. 2005. Poultry meat pathogens and its control. Int. J. Food Saf. 7:20-28.

38. McPherson, L. L. 1993. Understanding ORP's role in the disinfection process. Water Eng Manag. 140:29-31.

39. Mehyar, G., G. Blank, J. H. Han, A. Hydamaka, and R. A. Holley. 2005. Effectiveness of trisodium phosphate, lactic acid and commercial antimicrobials against pathogenic bacteria on chicken skin. Food Prot. Trends 25:351-362.
40. Midgley, J., and A. Small. 2006. Review of new and emerging technologies for red meat safety. Final report. Meat \& Livestock Australia. Available at: https://meatupdate. csiro.au/new/Review\%20of\%20new\%20 and $\% 20$ emerging $\% 20$ technlogies $\% 20$ for $\% 20$ red $\% 20$ meat $\% 20$ safety.pdf. Accessed 30 December 2015.

41. Park, H., Y. C. Hung, and R. E. Brackett. 2002. Antimicrobial effect of electrolyzed water for inactivating Campylobacter jejuni during poultry washing. Int. J. Food Microbiol. 72:77-83.

42. Rahman, S. M. E., J. Park, K. Bin Song, N. Al-Harbi, and D. H. Oh. 2012. Effects of slightly acidic low concentration electrolyzed water on microbiological, physicochemical, and sensory quality of fresh chicken breast. J. Food Sci. 71:35-41.

43. Rahman, S. M. E., J. Wang, and D. H. Oh. 2013. Synergistic effect of low concentration electrolyzed water and calcium lactate to ensure microbial safety, shelf life and sensory quality of fresh pork. Food Control 30:176-183.

44. Rivera-Garcia, A., L. Santos-Ferro, J. C. Ramirez-Orejel, L. T. Agredano-Moreno, L. F. Jimenez-Garcia, D. Paez-Esquiliano, E. Andrade-Esquivel, and J. A. Cano-Buendia.
2019. The effect of neutral electrolyzed water as a disinfectant of eggshells artificially contaminated with Listeria monocytogenes. Food Sci. Nutr. 7:2252-2260.

45. Shekarforoush, S. S., S. Basiri, H. Ebrahimnejad, and S. Hosseinzadeh. 2015. Effect of chitosan on spoilage bacteria, Escherichia coli and Listeria monocytogenes in cured chicken meat. Int. J. Biol. Macromol. 76:303-309.

46. Vandekinderen, I., F. Devlieghere, B. De Meulenaer, P. Ragaert, and J. Van Camp. 2009. Optimization and evaluation of a decontamination step with peroxyacetic acid for fresh-cut produce. Food Microbiol. 26:882-888.

47. Venkitanarayanan, K. S., G. O. Ezeike, Y. C Hung, and M. P. Doyle. 1999. Efficacy of electrolyzed oxidizing water for inactivating Escherichia coli O157:H7, Salmonella Enteritidis and Listeria monocytogenes. Appl. Environ. Microbiol. 65:4276-4279.

48. Wu, V. C. H., D. Y. C. Fung, and D. H. Kang. 2001. Evaluation of thin agar layer method for recovery of cold-injured foodborne pathogens. J. Rapid Methods Auto. Microbiol. 9:11-25. 